\title{
К ВОПРОСУ УСИЛЕНИЯ АДМИНИСТРАТИВНОЙ ОТВЕТСТВЕННОСТИ ЗА НАРУШЕНИЕ МИГРАЦИОННОГО ЗАКОНОДАТЕЛЬСТВА
}

\begin{abstract}
Аннотация: Данная статья посвящена рассмотрению основных изменений, вступивщих силу во второй половине 2013 г., которые касаются усиления ответственности за нарушение миграционного законодательства.Административно-правовое регулирование миграции населения является одной из самых актуальных проблем в сфере государственного управления. Обусловлено это рядом обстоятельств: демографические проблемы, недостаточная теоретическая проработанность роли и значения миграчионных процессов в демографическом развитии Российской Федерации. Эти и другие проблемы провоцируют целый ряд негативных последствий в сфере обеспечения правопорядка, а также социально-экономического развития страны. Для успешного решения проблем, связанных с миграцией, например, упорядочения рынка труда, повышения налогооблагаемой базы, снижения уровня преступности, необходим постоянный мониторинг правоприменительной практики, анализ текущего состояния и прогноз развития миграционных процессов. Методологическую основу статьи составили современные достижения теории познания. В процессе исследования применялись общефилософский, теоретический, общефилософские методы (диалектика, системный метод, анализ, синтез, аналогия, дедукция, наблюдение, моделирование), традиционно правовые методы (формально-логический), а также методы, используемые в конкретно-социологических исследованиях (статистические, экспертные оценки и др.). Нелегальная миграция с каждым годом все больше и больше заставляет обращать на себя внимание со стороны органов государственной власти. Правительство в различных контекстах ежегодно рассматривает проблемы миграции, определяет квоты на привлечение и использование в Российской Федерации иностранной рабочей силы, решает ряд иных вопросов в сфере реализации миграционной политики. Однако, несмотря на предпринимаемые меры, говорить о решении глобальных проблем в сфере обеспечения миграции пока не приходится.
\end{abstract}

Ключевые слова: миграция, политика, миграционный, ответственность, принуждение, полиция, усиление, ФМС, МВД, контроль.

Д ля успешного решения проблем, связанных с миграцией, например, упорядочения рынка труда, повышения налогооблагаемой базы,

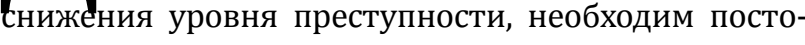
янный мониторинг правоприменительной практики, анализ текущего состояния и прогноз развития миграционных процессов. Такая комплексная задача предполагает осуществление, в первую очередь, мер политического, правового, организационного и иного характера при условии координации усилий федеральных органов государственной власти, органов власти субъектов Российской Федерации и органов местного самоуправления и гражданского общества в соответствии с законодательством, регламентирующим отношения в сфере миграции. С учетом общественного мнения в последние годы органами российского государства сделан ряд шагов по решению проблем, связанных с нелегальной миграцией. К ним необходимо отнести, в первую очередь, усиление юридической ответственности в соответствующей сфере и усложнение порядка въезда на территорию России иностранных граждан. 
Так, была введена административная ответственность за нарушение установленного порядка и (или) формы уведомления компетентных органов о привлечении иностранных граждан к трудовой деятельности на территории РФ. Ранее законодательством напрямую устанавливалась ответственность только за факт неуведомления компетентных органов, то есть несвоевременное уведомление не являлось основанием для привлечения к ответственности. Начиная с 9 августа 2013 года в качестве состава административного правонарушения рассматривается и нарушение порядка и (или) формы соответствующего уведомления. Иными словами, теперь работодатель может быть привлечен к административной ответственности и за пропуск установленного законом срока уведомления.

Статья 18.15 КоАП РФ дополнена частью 5, которая устанавливает новый вид ответственности работодателя: за неуведомление или нарушение установленного порядка и (или) формы уведомления компетентных органов при привлечении высококвалифицированных специалистов. Уведомления должны касаться:

- $\quad$ исполнения обязательств по выплате им заработной платы (вознаграждения);

- расторжения с ними трудового договора (гражданско-правового договора на выполнение работ, оказание услуг);

- предоставления им отпуска без сохранения заработной платы продолжительностью более одного календарного месяца в течение года;

- постановки высококвалифицированного специалиста на учет в налоговом органе.

Статья 18.8 КоАП РФ дополнена новой частью, устанавливающей административную ответственность с обязательным выдворением иностранного гражданина или лица без гражданства за пределы Российской Федерации в случае нарушения иностранным гражданином или лицом без гражданства режима пребывания (проживания) в Российской Федерации, выразившееся в отсутствии документов, подтверждающих право на пребывание (проживание) в Российской Федерации, или в случае утраты таких документов в неподаче заявления об их утрате в соответствующий орган либо в уклонении от выезда из Российской Федерации по истечении определенного срока пребывания.

За определенные правонарушения, совершенные на Москвы и Московской области, устанавливается специальная повышенная административная ответственность. К таким правонарушениям отно- сятся нарушение иностранным гражданином или лицом без гражданства правил въезда в Российскую Федерацию либо режима пребывания (проживания) в Российской Федерации, выразившееся:

- $\quad$ в нарушении установленных правил въезда в Российскую Федерацию, в нарушении правил миграционного учета, передвижения или порядка выбора места пребывания или жительства, транзитного проезда через территорию Российской Федерации, в неисполнении обязанностей по уведомлению о подтверждении своего проживания в Российской Федерации;

- в отсутствии документов, подтверждающих право на пребывание (проживание) в Российской Федерации, или в случае утраты таких документов в неподаче заявления об их утрате в соответствующий орган либо в уклонении от выезда из Российской Федерации по истечении определенного срока пребывания;

- несоответствии заявленной цели въезда в Российскую Федерацию фактически осуществляемой в период пребывания (проживания) в Российской Федерации деятельности или роду занятий.

Следует отметить, что административное выдворение за пределы Российской Федерации иностранного гражданина или лица без гражданства в форме контролируемого самостоятельного выезда из Российской Федерации не применяется к иностранным гражданам и лицам без гражданства, привлекаемым к административной ответственности за повторное в течение одного года совершение административного правонарушения.

Также, были внесены изменения в Федеральный закон № 114-Ф3 «0 порядке выезда из Российской Федерации и въезда в Российскую Федерацию», которые были направлены на уточнение оснований, при которых въезд в Российскую Федерацию иностранному гражданину или лицу без гражданства не разрешается и при которых въезд может быть не разрешен. Кроме того, Устанавливаются ранее отсутствовавшие основания, при которых въезд в Российскую Федерацию иностранному гражданину или лицу без гражданства не будет разрешен.

К числу новых направлений ответственности за нарушение миграционного законодательства можно отнести ведение ответственности за непринятие приглашающей стороной мер по обеспечению приглашенного иностранного гражданина ${ }^{1}$.

\footnotetext{
1 Подробнее см.: Облезова (Харитонова) А.О. Новое в миграционном законодательстве: введение ответственности за
} 
Как следует из ст. 34 Федерального закона от 25.07.2002 № 115-Ф3 «0 правовом положении иностранных граждан в Российской Федерации», административное выдворение иностранного гражданина за пределы РФ осуществляется за счет средств выдворяемого иностранного гражданина, а в случае отсутствия таких средств либо в случае, если иностранный работник принят на работу с нарушением установленного данным Законом порядка привлечения и использования иностранных работников, - за счет средств пригласившего его органа, дипломатического представительства или консульского учреждения иностранного государства, гражданином которого является выдворяемый иностранный гражданин, международной организации либо ее представительства, физического или юридического лица, оформившего приглашение на въезд в Российскую Федерацию, то есть приглашающей стороны.

В то же время законодатель определил, что неисполнение установленных обязанностей влечет за собой привлечение к ответственности, предусмотренной ст. 18.9 КоАП РФ, как для приглашающей, так и для принимающей стороны. Более того, с 11 января 2013 г. предусмотрена специальная ответственность за непринятие приглашающей стороной мер по материальному, медицинскому и жилищному обеспечению приглашенного ино- странного гражданина или лица без гражданства в период его пребывания в РФ.

Однако данный состав административного правонарушения представляется неопределенным. Прежде всего, не ясен состав мер по материальному, медицинскому и жилищному обеспечению приглашенного иностранного гражданина. Формулировка административной ответственности за непринятие приглашающей стороной мер по обеспечению иностранных граждан устанавливает широкие дискреционные полномочия для правоприменителей, что, в свою очередь, свидетельствует о потенциальной коррупциогенности нормы.

В заключение хотелось бы отметить, что любые меры ответственности должны быть четко определены в законе, причем таким образом, чтобы исходя из текста соответствующей нормы - в случае необходимости с помощью толкования, данного ей судами, - каждый мог предвидеть правовые последствия своих действий (бездействия). Неточность, неясность и неопределенность закона порождают возможность неоднозначного истолкования и, следовательно, произвольного применения его норм. В противном случае может иметь место противоречивая правоприменительная практика, что ослабляет гарантии государственной защиты прав, свобод и законных интересов граждан.

\section{Библиография:}

1. Куракин А.В. Иностранные граждане и лица без гражданства как субъекты административного права России // Государство и право. - 2001. - № 6.

2. Куракин А.В. Контроль органов внутренних дел за соблюдением правил пребывания в Российской Федерации иностранных граждан и лиц без гражданства. - М., 2002.

3. Облезова (Харитонова) А.О. Новое в миграционном законодательстве: введение ответственности за непринятие приглашающей стороной мер по обеспечению приглашенного иностранного гражданина // Миграционное право. - 2013. - № 1 .

4. Куракин А.В., Калинина Н.С. Административная ответственность и ее реализация в сфере обеспечения правопорядка при проведении собраний, митингов, демонстраций, шествий и пикетирования // Административное и муниципальное право. - 2013. - 3. - С. 270 - 279. DOI: 10.7256/1999-2807.2013.03.11.

5. Куракин А.В. Компетенция полиции в сфере реализации законодательства об административных правонарушениях // NB: Административное право и практика администрирования. - 2013. - 4. - С. 28 - 48. DOI: 10.7256/23069945.2013.4.8841. URL: http://www.e-notabene.ru/al/article_8841.html

6. Сизов И.Ю. Административно-правовой механизм миграционного учета // Административное и муниципальное право. - 2012. - 5. - С. 58 - 63.

7. Кашкина Е.В. Административный надзор органов внутренних дел за лицами, освобожденными из мест лишения свободы // Полицейская деятельность. - 2011. - 5. - С. 25 - 29.

8. Костенников М.В., Куракин А.В. К вопросу об основании административной ответственности в российском праве // NB: Административное право и практика администрирования. - 2013. - 10. - С. 75 - 88. DOI: 10.7256/23069945.2013.10.10153. URL: http://www.e-notabene.ru/al/article_10153.html

непринятие приглашающей стороной мер по обеспечению приглашенного иностранного гражданина // Миграционное право. 2013. № 1. С. 37 - 40. 


\section{Административное и муниципальное право $9(81) \cdot 2014$}

\section{References (transliterated):}

1. Kurakin A.V. Inostrannye grazhdane i litsa bez grazhdanstva kak sub"ekty administrativnogo prava Rossii // Gosudarstvo i pravo. - 2001. - № 6.

2. Kurakin A.V. Kontrol' organov vnutrennikh del za soblyudeniem pravil prebyvaniya v Rossiiskoi Federatsii inostrannykh grazhdan i lits bez grazhdanstva. - M., 2002.

3. Oblezova (Kharitonova) A.O. Novoe v migratsionnom zakonodatel'stve: vvedenie otvetstvennosti za neprinyatie priglashayushchei storonoi mer po obespecheniyu priglashennogo inostrannogo grazhdanina // Migratsionnoe pravo. 2013. - № 1.

4. Kurakin A.V., Kalinina N.S. Administrativnaya otvetstvennost' i ee realizatsiya v sfere obespecheniya pravoporyadka pri provedenii sobranii, mitingov, demonstratsii, shestvii i piketirovaniya // Administrativnoe i munitsipal'noe pravo. 2013. - 3. - S. 270 - 279. DOI: 10.7256/1999-2807.2013.03.11.

5. Kurakin A.V. Kompetentsiya politsii v sfere realizatsii zakonodatel'stva ob administrativnykh pravonarusheniyakh // NB: Administrativnoe pravo i praktika administrirovaniya. - 2013. - 4. - S. 28 - 48. DOI: 10.7256/2306-9945.2013.4.8841. URL: http://www.e-notabene.ru/al/article_8841.html

6. Sizov I.Yu. Administrativno-pravovoi mekhanizm migratsionnogo ucheta // Administrativnoe i munitsipal'noe pravo. 2012. - 5. - S. 58 - 63.

7. Kashkina E.V. Administrativnyi nadzor organov vnutrennikh del za litsami, osvobozhdennymi iz mest lisheniya svobody // Politseiskaya deyatel'nost'. - 2011. - 5. - S. 25 - 29.

8. Kostennikov M.V., Kurakin A.V. K voprosu ob osnovanii administrativnoi otvetstvennosti v rossiiskom prave // NB: Administrativnoe pravo i praktika administrirovaniya. - 2013. - 10. - S. 75 - 88. DOI: 10.7256/2306-9945.2013.10.10153. URL: http://www.e-notabene.ru/al/article_10153.html 